\title{
Study of the Influence of External Factors on the Germination of Bean Seeds
}

\author{
Lucia MIHALESCU ${ }^{1 *}$, Zorica VOȘGAN ${ }^{1}$, Oana MARE ROŞCA ${ }^{1}$, Monica MARIAN ${ }^{1}$, Stela JELEA ${ }^{1}$, \\ Flavia POP ${ }^{1}$, Anca DUMUȚA ${ }^{1}$, Aurel MAXIM ${ }^{2}$, Mirela CORDEA ${ }^{2}$ \\ ${ }^{1}$ Technical University of Cluj-Napoca, North University Center of Baia Mare, Romania \\ ${ }^{2}$ University of Agricultural Sciences and Veterinary Medicine, Cluj Napoca \\ * corresponding author: luciamihalescu@yahoo.com
}

Bulletin UASVM series Agriculture 73(2)/2016

Print ISSN 1843-5246; Electronic ISSN 1843-5386

DOI 10.15835/buasvmcn-agr: 12423

\begin{abstract}
The aim of our study was to follow the influence of the substrate, (single respectively double filter paper), the environment conditions (light, darkness), of the seed's measure and age, on the beans germination. These aspects were followed because the specialty literature correlates the loss of the germinative capacity with different external and internal factors. Three local varieties: $\mathrm{P}_{1}$ (Albenghino), $\mathrm{P}_{2}$ (Cannellini), $\mathrm{P}_{3}$ (Black Turtle), grown in Maramures County, with undetermined growth and different permeability of the seminal skin, were chosen for the experiment. One hundred seeds of every sort were placed in three replications. The energy and germinative faculty were determined, calculating the average values obtained at the replications. We noted that the $\mathrm{P}_{2}$ variety had the highest germinative faculty of $83.33 \%$ on double layer under light conditions, and the germination of $100 \%$ under darkness. The $\mathrm{P}_{1}$ variety is on the second place. The germinative faculty of the P3 variety is of only $70 \%$ on a single substrate and $80 \%$ on double layer. The germinative energy and faculty of the seeds provided from 2013 are diminished comparatively with those from 2014 . The local population P3 proved to be more influenced by age, with a germinative energy of $30 \%$ in 2013 and $60 \%$ in 2014 . The positive influence of the darkness conditions, both for the seeds provided from 2013 and 2014, was noted.
\end{abstract}

Keywords: darkness, germination, light, substrate.

Introduction. Bean is an important vegetable due to its high nutritional value (Bălteanu, 1993). Bean is a good precursory for most crops, being leguminous and weeding and yielding quite early (Gadea, 2003).

Aims and objectives. The aim of this study was to follow the influence of substrate under conditions of light and darkness, and the influence of seeds age on the germination of some local varieties of pole type bean. The objectives were the influence on the germination, of germination substrate (single layer and double layer), environment conditions (light/darkness), and seeds measure and age.

Materials and Methods. The experiments were carried out at the laboratory of vegetal physiology of the North University Center of Baia Mare. Three local varieties: P1 (Albenghino),
P2 (Cannellini), P3 (Black Turtle), grown in Maramures County, with undetermined growth and different permeability of the seminal tegument, were chosen for the experiment. The $\mathrm{P}_{1}$ variety has big, white seeds with medium tegument thickness, $\mathrm{P}_{2}$ has medium, yellow seeds with thinner tegument, and $\mathrm{P}_{3}$ has small, dark violet seeds with thick tegument. Germinators with single layer and respectively double layers of filter paper were prepared. One hundred seeds of every sort were laid in three replications. Different age seeds, provided from the harvests of the years 2013 and 2014, were used. Half of the germinators were kept in light, and the other half in darkness. The germinative energy was determined after 4 days and the germinative faculty after 8 days.

Results and Discussion. It was observed that the germinative substrate influences both 
Tab.1. Germinative energy and faculty for the $\mathrm{P}_{1}, \mathrm{P}_{2}$ and $\mathrm{P}_{3}$ varieties, under conditions of light and darkness

\begin{tabular}{|c|c|c|c|c|c|}
\hline No & $\begin{array}{l}\text { Analyzed } \\
\text { Seed } \\
\text { (Variety) }\end{array}$ & $\begin{array}{c}\text { Germinative } \\
\text { substrate }\end{array}$ & $\begin{array}{c}\text { Germinative } \\
\text { energy }\end{array}$ & $\begin{array}{l}\text { Germinative } \\
\text { faculty }\end{array}$ & $\begin{array}{c}\text { Environment } \\
\text { conditions } \\
20-22^{\circ} \mathrm{C}\end{array}$ \\
\hline \multirow{4}{*}{1} & \multirow{4}{*}{$\mathrm{P}_{1}$ (Albenghino) } & S.S. & 23.33 & 60 & \multirow{2}{*}{ light } \\
\hline & & S.D. & 50 & 70 & \\
\hline & & S.S. & 60 & 83.33 & \multirow{2}{*}{ darkness } \\
\hline & & S.D. & 70 & 93.33 & \\
\hline \multirow{4}{*}{2} & \multirow{4}{*}{$\begin{array}{c}\mathrm{P}_{2} \\
\text { (Cannellini) }\end{array}$} & S.S. & 43.33 & 70. & \multirow{2}{*}{ light } \\
\hline & & S.D. & 66.66 & 83.33 & \\
\hline & & S.S. & 70 & 93.33 & \multirow{2}{*}{ darkness } \\
\hline & & S.D. & 83.33 & 100 & \\
\hline \multirow{4}{*}{3} & \multirow{4}{*}{$\frac{\mathrm{P}_{3}}{\text { (Black Turtle) }}$} & S.S. & 20 & 40 & \multirow{2}{*}{ light } \\
\hline & & S.D. & 33.33 & 60 & \\
\hline & & S.S. & 30 & 70 & \multirow{2}{*}{ darkness } \\
\hline & & S.D. & 50 & 80 & \\
\hline
\end{tabular}

Note: S.S.- single stratum; S.D.- double stratum

the energy and germination faculty, in all tested varieties, both under conditions of light and darkness. This can be observed in Table1.

We note that the germinative energy, for all three varieties, under light conditions, was lower on single stratum, with higher values on double stratum, as on the first place has been the $\mathrm{P}_{2}$ variety with $66.66 \%$, followed by $\mathrm{P}_{1}(50 \%)$, and $\mathrm{P}_{3}(33.33 \%)$. Darkness had a stimulating effect on the germinative energy for all varieties, reaching $83.33 \%$ for the P2 variety, $70 \%$ for the P1 variety, and $50 \%$ for the P3 variety.

Double layers positively influenced the germination faculty of the variety $\mathrm{P}_{1}(70 \%)$, and that on simple layer - which was $60 \%$, under light conditions. It well germinated on both types of layers - 93.33\% and $83.33 \%$ - under darkness. A germinative faculty of $93.33 \%$ respectively $100 \%$ was registered for the $\mathrm{P}_{2}$ variety on both germinative layers, under darkness. The lowest values of germination were recorded for the $\mathrm{P}_{3}$ variety, maybe due to the tegument measure, color and thickness. Following the influence of the seeds age, it has been observed that the germinative energy and faculty of those made available from
2013 are more diminished comparatively with those of 2014 . The $\mathrm{P}_{3}$ variety proved to be more influenced by age, with the germinative energy of 30\% (2013) and 60\% (2014) under light conditions, and $50 \%$ and respectively $70 \%$ under darkness. A positive influence of the darkness condition was observed both for the seeds of the 2013 harvest as well as that of 2014 . The $\mathrm{P}_{2}$ variety was placed on the first place, under darkness conditions, with a germinative faculty of $90 \%$ in 2013 , respectively $100 \%$ in 2014 , followed by $\mathrm{P}_{1}$ with $80 \%$ (2013) and 93.33\% (2014), and $\mathrm{P}_{3}$ with 70\% (2013) and 83.33\% (2014).

Conclusion. The color, measure and thickness of seminal tegument influence the germinative energy and faculty, this being proved by the recorded results. The P2 variety meets a germination of $100 \%$ under darkness for the seeds of 2014 , it being followed by $\mathrm{P}_{1}$ with $93.33 \%$, then by $\mathrm{P}_{3}$ with $83.33 \%$, these values being higher than those recorded for the seeds harvested in 2013.

\section{REFERENCES}

1. Bâlteanu G (1993). Fitotehnie, vol.II. Ed.Ceres, Bucuresti.

2. Gâdea Ș (2003). Fiziologia vegetala. Ed.Academic Pres, Cluj-Napoca 